\title{
Gambaran pola konsumsi makanan pada ibu hamil di kota Manado
}

\author{
${ }^{1}$ Bezaliel R. Narasiang \\ ${ }^{2}$ Nelly Mayulu \\ ${ }^{2}$ Shirley Kawengian
}

\author{
${ }^{1}$ Kandidat Skripsi Fakultas Kedokteran Universitas Sam Ratulangi Manado \\ ${ }^{2}$ Bagian Ilmu Gizi Fakultas Kedokteran Universitas Sam Ratulangi Manado \\ Email: bezaliel.narasiang@ hotmail.com
}

\begin{abstract}
Pregnancy is a critical time or a golden period of the brief human growth and development time, a part of the Window of Opportunity, which affects the maternal and fetal health. Throughout the first phase of pregnancy, pregnant women need more food intake, accurate eating pattern, and also a balanced macronutrient intake. An adequate intake of food is very important to support the physical health and development of fetal mental health also decrease the risk of pregnancy complications. This study was aimed to obtain the description of food consumption pattern in pregnant women in Manado. This was a descriptive study with a cross sectional design using Food Frequency Questionnaire (FFQ) to obtain data of pregnant women in 5 public health centers in Manado from September to October 2016. Based on the FFQ data given by 181 respondents, the consumption of pregnant women in Manado was as follows: carbohydrate $159.97 \mathrm{~g} /$ day, protein $79.15 \mathrm{~g} / \mathrm{day}$, and fat $124.74 \mathrm{~g} /$ day. The most common foods consumed by the pregnant women were rice (carbohydrate), saltwater fish (protein), and coconut oil (fat). Meanwhile, chicken was rarely consumed $(81.22 \%)$ and eel was never consumed $(100 \%)$. Conclusion: Pregnant women in Manado had a food pattern that was lack in carbohydrate and high in fat according to pregnant women Recommended Dietary Allowances (RDA) in Indonesia.
\end{abstract}

Keywords: pregnant women, food pattern, food frequency questionnaire

\begin{abstract}
Abstrak: Kehamilan merupakan masa kritis atau masa emas tumbuh kembang manusia yang singkat, bagian dari Window of Opportunity, yang memengaruhi kesehatan ibu dan janin. Sepanjang tahap awal kehamilan, ibu hamil membutuhkan konsumsi makanan yang lebih dari semula, pola makanan yang tepat, juga asupan makronutrien yang seimbang. Pola asupan makanan yang adekuat sangat penting untuk menunjang kesehatan fisik, perkembangan mental janin, dan menurunkan komplikasi kehamilan. Penelitian ini bertujuan untuk mendapatkan gambaran umum pola konsumsi makanan pada ibu hamil di Kota Manado. Jenis penelitian ialah deskriptif dengan desain potong lintang menggunakan Food Frequency Questionnaire (FFQ) pada ibu hamil di 5 puskesmas di Kota Manado selama bulan September-Oktober 2016. Berdasarkan perolehan data FFQ dari 181 responden, didapatkan bahwa konsumsi karbohidrat ibu hamil di Kota Manado sebanyak 159,97gr/hari, protein sebanyak 79,15gr/hari, dan lemak sebanyak 124,74gr/hari. Makanan tersering dan terbanyak yang dikonsumsi ialah beras (karbohidrat), ikan air laut (protein), dan minyak kelapa (lemak). Ayam merupakan makanan yang jarang dikonsumsi $(81,22 \%)$ dan belut merupakan makanan yang tidak pernah dikonsumsi ibu hamil (100\%). Simpulan: Ibu hamil di Kota Manado memiliki pola makan yang rendah karbohidrat dan tinggi lemak berdasarkan AKG ibu hamil di Indonesia.
\end{abstract}

Kata kunci: ibu hamil, pola makan, food frequency questionnaire 
Kehamilan merupakan masa kritis atau masa emas tumbuh kembang manusia yang singkat, bagian dari Window of Opportunity, yang mempengaruhi kesehatan ibu dan janin. ${ }^{1}$ Periode Window of Opportunity merupakan kesempatan singkat untuk melakukan sesuatu yang menguntungkan. ${ }^{2}$ Pada bidang ilmu gizi, periode Window of Opportunity berkisar dari sebelum kehamilan sampai usia anak mencapai 2 tahun atau dikenal dengan 1000 hari pertama kehamilan. ${ }^{3}$

Sepanjang tahap kehamilan, ibu hamil membutuhkan konsumsi makanan yang lebih dari semula, pola makanan yang tepat, juga asupan macronutrients yang seimbang. Pemenuhan peningkatan asupan makanan ini berperan penting terhadap kesehatan ibu hamil dan janin. ${ }^{4,5}$

Pola asupan makanan yang adekuat sejak tahap awal kehamilan sangat penting untuk menunjang kesehatan fisik dan perkembangan mental janin. ${ }^{6}$

Kekurangan gizi pada kehamilan akan menghambat pertumbuhan dan perkembangan janin, serta menghambat pembentukan fungsi otak janin. Janin yang kekurangan gizi berisiko lahir dengan berat badan rendah dan ketika tumbuh dewasa akan berisiko lebih tinggi untuk menderita penyakit degeneratif (diabetes, hipertensi, penyakit jantung, dan stroke) daripada yang tidak kekurangan gizi. ${ }^{7}$ Setiap tahun di negara berkembang, kurang lebih 13 juta bayi lahir dengan gangguan pertumbuhan sejak dalam kandungan dan sebanyak 20 juta bayi lahir dengan berat badan lahir rendah. ${ }^{8,9}$

Riskesdas (2013) menyatakan bahwa sebesar 24,2\% ibu hamil di Indonesia masuk dalam status risiko Kurang Energi Kronik (KEK). Prevalensi risiko KEK tertinggi di Nusa Tenggara Timur $(45,5 \%)$ dan prevalensi risiko KEK terendah di Bali $(10,1 \%)$. Secara keseluruhan, dengan bandingan data tahun 2007, prevalensi risiko KEK ibu hamil tahun 2013 naik pada semua kelompok umur dengan kenaikan mencapai $15,1 \% .^{10}$

Berdasarkan

Brazilian Diabetes Society Congress (2015), menggunakan
Index Quality Diet (IQD) diperoleh hasil bahwa sebesar 48,4\% konsumsi makanan ibu hamil tidak adekuat. Hal ini disebabkan oleh tingginya konsumsi daging dan lemak, dan rendahnya konsumsi sayuran dan dairy products pada ibu hamil. ${ }^{11}$

Berdasarkan Schoenaker (2016), konsumsi lemak, kolesterol, dan zat besi yang tinggi dalam makanan (termasuk daging dan telur) selama kehamilan dapat meningkatkan risiko obesitas gestasional pada ibu hamil. ${ }^{12}$ Western Dietary Pattern dan Mediterranean-style Dietary Pattern berpengaruh dalam kejadian risiko obesitas dan malnutrisi selama kehamilan. ${ }^{13-15}$

Ali $\mathrm{H}$, et al (2013) melalui metode Food Frequency Questionnaire (FFQ) pada ibu hamil di United Arab Emirates, menunjukkan bahwa ibu hamil dengan berat badan ideal cenderung mengkonsumsi buah-buahan dan jus buah dibanding ibu hamil yang overweight. ${ }^{16}$

Penelitian ini bertujuan untuk mengetahui pola konsumsi makanan pada ibu hamil di Kota Manado.

\section{METODE PENELITIAN}

Desain penelitian yang digunakan adalah penelitian deskriptif observasional dengan pendekatan potong lintang (cross sectional study). Penelitian dilakukan pada bulan September-Oktober 2016 di 5 puskesmas yang melaksanakan rawat inap ibu hamil di 5 kecamatan yang berbeda di Kota Manado, Provinsi Sulawesi Utara. Populasi penelitian adalah ibu-ibu hamil di Kota Manado. Sampel penelitian ini adalah ibu hamil trimester berapapun yang datang ke lokasi penelitian. Variabel penelitian yaitu pola konsumsi makanan dan ibu hamil. Pemeriksaan ini dilakukan dengan melakukan wawancara dengan responden secara langsung dengan menggunakan metode Food Frequency Questionnaire $(F F Q)$ yang terdiri dari 9 Kelompok Makanan (KM) dengan total sebanyak 86 jenis makanan yang telah disesuaikan dengan jenis makanan lokal masyarakat Provinsi Sulawesi Utara. Data hasil penelitian dimasukkan pada tabel FFQ dan diolah menggunakan Microsoft Excel. 


\section{HASIL PENELITIAN}

Hasil penelitian yang dilaksanakan di 5 puskesmas di Kota Manado, terdapat 181 ibu hamil yang telah bersedia untuk diwawancarai, terbanyak berada dalam kelompok umur 20-25 tahun, yaitu 76 orang $(41,99 \%), 73$ orang pada kelompok umur 26-35 tahun (40,33\%), 20 orang pada kelompok umur $<20$ tahun $(11,05 \%)$, dan 12 orang berada pada kelompok umur $>35$ tahun $(6,63 \%)$.

Tabel 1. Distribusi berdasarkan umur ibu hamil di Kota Manado.

\begin{tabular}{ccc}
\hline Umur & $\mathbf{N}$ & $\mathbf{( \% )}$ \\
\hline$<20$ tahun & 20 & 11,05 \\
20-25 tahun & 76 & 41,99 \\
26-35 tahun & 73 & 40,33 \\
$>35$ tahun & 12 & 6,63 \\
Total & 181 & 100 \\
\hline
\end{tabular}

Pada penelitian didapatkan persentase pendidikan tertinggi yaitu telah tamat Sekolah Menengah Atas (SMA) dengan jumlah 118 orang $(65,19 \%)$. Tidak ada yang tidak tamat Sekolah Dasar (SD).

Tabel 2. Ditribusi berdasarkan pendidikan terakhir ibu hamil di Kota Manado.

\begin{tabular}{ccc}
\hline Pendidikan & $\mathbf{N}$ & $\mathbf{( \% )}$ \\
\hline Tidak tamat SD & 0 & 0 \\
Tamat SD & 6 & 3,31 \\
Tamat SMP & 38 & 20,99 \\
Tamat SMA & 118 & 65,19 \\
Tamat D3/S1 & 19 & 10,50 \\
Total & 181 & 100 \\
\hline
\end{tabular}

Data hasil penelitian didapatkan bahwa bahan makanan yang paling sering dikonsumsi oleh 173 orang yaitu beras $(95,58 \%)$. Ikan laut diurutan kedua dengan jumlah 103 orang $(56,91)$. Sedangkan ayam hanya sering dikonsumsi oleh 3 orang $(1,66 \%)$ (Tabel 3).

Hasil penelitian didapatkan bahwa bahan makanan yang jarang dikonsumsi yaitu ayam dengan frekuensi 147 orang $(81,22 \%)$. Mie berada di urutan kedua sebagai bahan makanan yang jarang dikonsumsi oleh 135 orang (74,59\%)
(Tabel 4).

Tabel 3. Ditribusi bahan makanan berdasarkan frekuensi tertinggi untuk kategori sering

\begin{tabular}{|c|c|c|c|}
\hline \multirow{2}{*}{$\begin{array}{l}\text { KM } \\
\text { FFQ }\end{array}$} & \multicolumn{2}{|c|}{ Frekuensi } & \multirow{2}{*}{$\begin{array}{c}\text { Bahan } \\
\text { Makanan }\end{array}$} \\
\hline & $\mathrm{n}$ & $\%$ & \\
\hline I & 173 & 95,58 & Beras \\
\hline II & 10 & 5,52 & Tahu \\
\hline III & 3 & 1,66 & Ayam \\
\hline IV & 103 & 56,91 & Ikan Air Laut \\
\hline V & 23 & 12,71 & Tomat \\
\hline VI & 4 & 2,21 & Telur Ayam \\
\hline VII & 17 & 9,39 & Pisang \\
\hline VIII & 57 & 31,49 & Minyak Kelapa \\
\hline IX & 83 & 45,86 & Garam Dapur \\
\hline
\end{tabular}

Tabel 4. Ditribusi bahan makanan berdasarkan frekuensi tertinggi untuk kategori jarang

\begin{tabular}{cccl}
\hline KM & \multicolumn{2}{c}{ Frekuensi } & \multirow{2}{*}{$\begin{array}{c}\text { Bahan } \\
\text { Makanan }\end{array}$} \\
\cline { 2 - 3 } FFQ & n & $\%$ & \\
I & 135 & 74,59 & Mie \\
II & 128 & 70,72 & Tahu \\
III & 147 & 81,22 & Ayam \\
IV & 81 & 44,75 & Ikan Air Tawar \\
V & 120 & 66,30 & Kangkung \\
VI & 124 & 68,51 & Telur Ayam \\
VII & 109 & 60,22 & Pepaya \\
VIII & 90 & 49,71 & Minyak Kelapa \\
IX & 118 & 65,19 & Gula Pasir \\
\hline
\end{tabular}

Berdasarkan hasil penelitian didapatkan bahwa bahan makanan yang tidak pernah dikonsumsi oleh 181 orang yaitu belut (100\%). Telur asin di urutan kedua sebagai bahan makanan yang tidak pernah dikonsumsi dengan jumlah 179 orang $(98,90 \%)$ (Tabel 5).

Pada penelitian didapatkan hasil bahan makanan dengan rata-rata konsumsi terbanyak yaitu beras dengan jumlah $303,67 \mathrm{gr} /$ hari. Minyak kelapa menempati urutan kedua sebagai bahan makanan dengan rata-rata konsumsi tertinggi setelah beras, yaitu sebesar 118,63gr/hari (Tabel 6).

Pada penelitian didapatkan hasil bahan makanan dengan rata-rata konsumsi terendah yaitu belut dengan jumlah 0,00 $\mathrm{gr} /$ hari, diikuti Cornef beef dengan rata-rata 
konsumsi terendah setelah belut, yaitu sebesar 0,02gr/hari (Tabel 7).

Tabel 5. Ditribusi bahan makanan berdasarkan frekuensi tertinggi untuk kategori tidak pernah

\begin{tabular}{cccl}
\hline KM & \multicolumn{2}{c}{ Frekuensi } & \multicolumn{1}{c}{$\begin{array}{c}\text { Bahan } \\
\text { Makanan }\end{array}$} \\
\cline { 2 - 3 } FFQ & $\mathrm{n}$ & $\%$ & Singkong \\
I & 119 & 65,75 & Singa \\
II & 177 & 97,79 & Kelapa Tua \\
& 177 & 97,79 & Emping \\
III & 177 & 97,79 & Corned Beef \\
IV & 181 & 100 & Belut \\
V & 176 & 97,24 & Pare \\
VI & 179 & 98,90 & Telur Asin \\
VII & 169 & 93,37 & Jambu Air \\
& 169 & 93,37 & Jambu Biji \\
VIII & 170 & 93,92 & Yoghurt \\
IX & 166 & 91,71 & Gula Kelapa \\
& 166 & 91,71 & Krupuk Ikan \\
\hline
\end{tabular}

Tabel 6. Ditribusi bahan makanan berdasarkan rata-rata konsumsi tertinggi

\begin{tabular}{ccl}
\hline $\begin{array}{c}\text { KM } \\
\text { FFQ }\end{array}$ & $\begin{array}{c}\text { Rata-rata tertinggi } \\
\text { (gr/hari) }\end{array}$ & $\begin{array}{c}\text { Bahan } \\
\text { Makanan }\end{array}$ \\
\hline I & 303,67 & Beras \\
II & 49,48 & Tahu \\
III & 18,09 & Ayam \\
IV & 102,55 & Ikan Air Laut \\
V & 49,32 & Kangkung \\
VI & 22,40 & Telur Ayam \\
VII & 35,95 & Pisang \\
VIII & 118,63 & Minyak Kelapa \\
IX & 20,97 & Gula Pasir \\
\hline
\end{tabular}

Tabel 7. Ditribusi bahan makanan berdasarkan rata-rata konsumsi terendah

\begin{tabular}{ccl}
\hline $\begin{array}{c}\text { KM } \\
\text { FFQ }\end{array}$ & $\begin{array}{c}\text { Rata-rata terendah } \\
\text { (gr/hari) }\end{array}$ & $\begin{array}{c}\text { Bahan } \\
\text { Makanan }\end{array}$ \\
\hline I & 9,52 & Kentang \\
II & 0,18 & Kelapa Tua \\
III & 0,02 & Corned Beef \\
IV & 0,00 & Belut \\
V & 0,12 & Pare \\
VI & 0,14 & Telur Asin \\
VII & 0,21 & Durian \\
VIII & 0,88 & Margarine \\
IX & 0,41 & Gula Kelapa \\
\hline
\end{tabular}

Berdasarkan hasil penelitian didapatkan bahwa bahan makanan sumber karbohidrat yang paling banyak dikonsumsi yaitu beras $(303,67 \mathrm{gr} / \mathrm{hari})$, bahan makanan sumber protein yang paling banyak dikonsumsi yaitu ikan air laut (102,55gr/hari), dan bahan makanan sumber lemak paling banyak dikonsumsi yaitu minyak kelapa $(118,63 \mathrm{gr} / \mathrm{hari})$.

Tabel 8. Ditribusi rata-rata tertinggi bahan makanan berdasarkan zat gizi makro

\begin{tabular}{lcl}
\hline \multicolumn{1}{c}{ Zat Gizi } & $\begin{array}{c}\text { Rata-rata } \\
\text { (gr/hari) }\end{array}$ & Bahan Makanan \\
\hline Karbohidrat & 303,67 & Beras \\
Protein & 102,55 & Ikan Air Laut \\
Lemak & 118,63 & Minyak Kelapa \\
\hline
\end{tabular}

Pada penelitian didapatkan bahwa ratarata konsumsi bahan makanan sumber karbohidrat yaitu sebesar 159,97gr/hari. Rata-rata konsumsi bahan makanan sumber protein yaitu sebesar 79,15gr/hari sedangkan rata-rata konsumsi bahan makanan sumber lemak yaitu sebesar 124,74gr/hari (Tabel 9).

Tabel 9. Ditribusi rata-rata konsumsi bahan makanan berdasarkan zat gizi makro

\begin{tabular}{cc}
\hline Zat Gizi & Rata-rata $\mathbf{( g r} /$ hari) \\
\hline Karbohidrat & 159,97 \\
Protein & 79,15 \\
Lemak & 124,74 \\
\hline
\end{tabular}

\section{BAHASAN}

Ibu hamil yang merupakan sampel penelitian ini berjumlah sebanyak 181 orang. Umur ibu hamil paling banyak berada pada kelompok umur 20-25 tahun dengan jumlah 76 orang $(41,99 \%)$, diikuti oleh kelompok umur 26-35 tahun, sebanyak 73 orang (40,33\%). Rentang umur 20-35 tahun merupakan umur yang ideal dan pas bagi wanita untuk hamil. Bagi wanita yang hamil diatas 35 tahun akan semakin tinggi resiko kehamilannya dibanding yang hamil dibawah 35 tahun. ${ }^{17,18}$ Berdasarkan World Health Organization (2014), resiko kematian naik 2 kali lipat lebih tinggi pada ibu hamil yang 20 tahun kebawah. ${ }^{19}$ 
Sebagian besar ibu hamil yang menjadi responden dalam penelitian ini telah tamat SMA, yaitu sebanyak 118 orang $(65,19 \%)$. Tinggi rendahnya tingkat pendidikan ibu hamil berpengaruh terhadap tingkat pengetahuan terhadap perawatan kesehatan selama hamil dan pemeriksaan kehamilan berkala. Semakin tinggi tingkat pendidikan ibu hamil, semakin bijaksana pula sikap ibu untuk memperhatikan kehamilannya. ${ }^{20,21}$

Nutrisi yang seimbang merupakan hal yang penting diperhatikan ibu hamil. Melalui pola makan yang tepat, ibu hamil dapat memenuhi kebutuhan nutrisi bagi tumbuh kembang janin maupun bagi kesehatan ibu. ${ }^{4}$ Pola makan merupakan gambaran mengenai macam dan jumlah bahan makanan yang dimakan tiap hari oleh suatu orang dan merupakan ciri khas untuk suatu kelompok masyarakat tertentu. Berdasarkan Panduan Gizi Seimbang tahun 2014, karbohidrat, protein, dan lemak merupakan zat gizi makro yang sangat dibutuhkan ibu hamil. $^{22,23}$

Hasil penelitian terhadap 86 jenis bahan makanan dalam Food Frequency Questionnaire (FFQ) menunjukkan bahwa beras merupakan bahan makanan sumber karbohidrat yang paling sering dan paling banyak dikonsumsi ibu hamil di Kota Manado, yaitu berjumlah 173 orang $(95,58 \%)$ dengan rata-rata konsumsi sebanyak 303,67 gr/hari. Hal ini sesuai dengan penelitian pola makan terhadap ibu hamil yang dilakukan oleh Widy (2014), dimana beras menjadi sumber karbohidrat utama yang paling sering dikonsumsi ibu selama hamil. ${ }^{24}$ Hal yang sama juga dibahas oleh Hessie (2009) yang menyatakan bahwa beras termasuk makanan pokok di Indonesia yang sering dikonsumsi dan diproduksi hingga diekspor keluar negeri. Lebih dari setengah penduduk dunia juga mengonsumsi beras sebagai makanan pokok. ${ }^{25}$ Christianto (2013) menyatakan bahwa konsumsi beras masyarakat Indonesia cukup tinggi yaitu sebesar $139,5 \mathrm{~kg}$ per tahunnya. Konsumsi beras di Indonesia lebih besar 2 kali lipat dari konsumsi beras dunia yang berada pada angka $60 \mathrm{~kg}$ per tahun. ${ }^{26}$
Berdasarkan zat gizi protein, ikan air laut menjadi bahan makanan dengan frekuensi tertinggi kategori sering yang dikonsumsi ibu hamil di Kota Manado, yaitu sebanyak 103 orang $(56,91 \%)$ dengan jumlah konsumsi sebesar 102,55 gr/hari. Hasil ini berbeda dengan hasil penelitian FFQ oleh Widy (2014) yang menunjukkan bahwa ikan berada di urutan kedua setelah ayam sebagai bahan makanan yang paling sering dikonsumsi ibu hamil. ${ }^{24}$ Hal ini dapat dikarenakan perbedaan lokasi penelitian. Kota Manado yang berlokasi dipesisir pantai dengan kekuatan ekonomi yang tinggi terhadap hasil laut, membuat ikan air laut mudah didapat dan ditemukan di kota ini. Berdasarkan Kementrian Kelautan Dan Perikanan Republik Indonesia, jumlah konsumsi ikan di Indonesia menunjukkan kenaikan sebesar $6,27 \%$ dalam 5 tahun terakhir (20112015). ${ }^{27,28}$

Bahan makanan sumber lemak dengan frekuensi tertinggi kategori sering yang dikonsumsi ibu hamil di Kota Manado adalah minyak kelapa, yaitu sejumlah 57 orang $(31,49 \%)$ dengan rata-rata mencapai 118,63gr/hari. Hal ini sesuai dengan penelitian Torjusen, et al (2012) yang menunjukkan bahwa konsumsi minyak, kentang dan buah-buahan mengalami peningkatan yang cukup signifikan pada pola makan ibu hamil di Norwegia. Data dari Badan Pusat Statistik Indonesia pada tahun 2013 menunjukkan bahwa konsumsi minyak kelapa di Indonesia sejak tahun 2006 masih cukup tinggi dikonsumsi oleh masyarakat Indonesia. Sulawesi Utara juga merupakan provinsi dengan total kapasitas produksi minyak kelapa tertinggi di Indonesia, sehingga minyak kelapa dapat dengan mudah ditemukan dan diperoleh dengan harga terjangkau di ibukota provinsi, yaitu kota Manado ${ }^{29,30}$

Berdasarkan frekuensi tertinggi untuk kategori jarang dan tidak pernah, diperoleh hasil bahwa ibu hamil di Kota Manado paling jarang mengonsumsi ayam yaitu sejumlah 147 orang $(81,22 \%)$, dan sebanyak 181 ibu hamil di Kota Manado tidak pernah mengonsumsi belut (100\%). 
Hal ini dapat dikaitkan dengan kebiasaan berpantang terhadap suatu jenis makanan pada saat kehamilan, seperti yang diteliti oleh Praditama A D tentang pola makan pada ibu hamil dan pasca melahirkan. Dalam penelitiannya, ditemukan bahwa sebagian ibu hamil di Nganjuk berpantang terhadap ayam karena dianggap akan membuat jahitan lama kering. ${ }^{31}$

Hasil penelitian jumlah rata-rata asupan zat gizi makro pada ibu hamil sesuai data pada FFQ, menunjukkan bahwa ibu hamil di Kota Manado mengonsumsi karbohidrat sebesar $159,97 \mathrm{gr} /$ hari, protein sebesar 79,15gr/hari, dan lemak sebesar 124,74gr/hari. Berdasarkan Dietary Reference Intakes (Institute of Medicine), asupan ideal karbohidrat pada ibu hamil adalah sebesar $175 \mathrm{gr} /$ hari dan untuk protein sebesar $71 \mathrm{gr} /$ hari. Disamping itu, sesuai dengan Permenkes nomor 75 tahun 2013 tentang Angka Kecukupan Gizi (AKG) di Indonesia, asupan ideal karbohidrat untuk ibu hamil adalah sebesar 334-349gr/hari, protein sebesar 76-79gr/hari, dan lemak sebesar $81-85 \mathrm{gr} /$ hari. $^{32-34}$

$$
\text { Dengan demikian, walaupun }
$$
karbohidrat merupakan zat gizi yang paling banyak dikonsumsi oleh ibu hamil di Kota Manado (159,97gr/hari), namun jumlah tersebut masih cukup rendah dibanding standar AKG untuk ibu hamil di Indonesia. Hasil rata-rata konsumsi protein pada ibu hamil di Kota Manado (79,15gr/hari) menunjukkan hasil yang cukup sesuai dengan nilai standar AKG ibu hamil, namun berada di batas atas rentang konsumsi lemak ideal untuk ibu hamil di Indonesia. Sedangkan untuk konsumsi lemak (124,74gr/hari), memiliki angka yang cukup tinggi.

\section{SIMPULAN}

Berdasarkan hasil penelitian pola konsumsi makanan pada ibu hamil di Kota Manado, dapat disimpulkan bahwa mengacu pada Permenkes nomor 75 tahun 2013 tentang Angka Kecukupan Gizi di Indonesia, ibu hamil di Kota Manado memiliki pola makan yang rendah karbohidrat $(159,97 \mathrm{gr} / \mathrm{hari})$, cukup protein
$(79,15 \mathrm{gr} / \mathrm{hari})$ dan tinggi lemak (124,74gr/hari).

Beras merupakan bahan makanan sumber karbohidrat yang paling banyak dikonsumsi ibu hamil di Kota Manado yaitu sebanyak 303,67gr/hari, ikan air laut merupakan bahan makanan sumber protein yang paling banyak dikonsumsi ibu hamil di Kota Manado yaitu sebanyak 102,55 gr/hari, dan minyak kelapa merupakan bahan makanan sumber lemak yang paling banyak dikonsumsi ibu hamil di Kota Manado yaitu sebanyak 118,63 gr/hari.

\section{SARAN}

Perlu dilakukan sosialisasi mengenai pedoman gizi seimbang, khususnya bagi ibu-ibu hamil dan perlu dilakukan edukasi pada ibu hamil di Kota Manado untuk lebih meningkatkan konsumsi karbohidrat dan menurunkan konsumsi lemak. Selain itu, perlu dilakukan penelitian pola konsumsi makanan lanjutan dengan rekomendasi menggunakan gabungan metode FFQ dan Food Recall 24 jam.

\section{DAFTAR PUSTAKA}

1. World Bank. Repositioning nutrition as central to development: a strategy for large-scale action. Washington DC: World Bank; 2006.

2. Oxford Dictionary of English. Definition: window of opportunity. [diakses 9 September 2016]. Tersedia dari http://www.oxforddictionaries.com/d efinition/english/window-ofopportunity.

3. Barker DJP. Introduction: the window of opportunity. J Nutr. 2007; 137: 10589.

4. Academy for Educational Development (US). Maternal nutrition during pregnancy and lactation. Washington: Linkages; 2004.

5. Institute of Medicine. Weight gain during pregnancy: reexamining the guidelines. Washington: National Academies Press; 2009.

6. World Health Organization. Comprehensive implementation plan on maternal, infant and young child nutrition. 2014.

7. Popkin BM, Richards MK, Monteiro C. 
Stunting is associated with overweight in children of four nations that are undergoing the nutrition transition. J Nutr 1996; 126:3009-16.

8. de Onis M, Blossner M, Vilar J. Levels and patterns of intrauterine growth retardation in developing countries. European Journal of Clinical Nutrition, 1998; 52(Suppl.1):S5-S15.

9. United Nations Children's Fund and World Health Organization. Low birthweight: country, regional and global estimates. New York, United Nations Children's Fund, 2004.

10. Kementrian Kesehatan RI. Riset kesehatan dasar: riskesdas 2013. Jakarta: Badan Penelitian dan Pengembangan Kesehatan, 2013.

11.de Sousa Moreira Reis $L$, de Mattos Paranhos Calderon I, Bolognani C, Dias A. Food consumption rated by quality index diet (IQD) in pregnant women with gestational diabetes mellitus. Diabetology \& Metabolic Syndrome 2015; 7(Suppl 1):A67.

12.Schoenaker D, Mishra G, Callaway L, Muthu S. The role of energy, nutrients, foods, and dietary patterns in the development of gestational diabetes mellitus: a systematic review of observational studies. Am Diabetes Assoc 2010; 39:16-23.

13.Fung TT, Schulze M, Manson JE, Willett WC, Hu FB. Dietary patterns, meat intake, and the risk of type 2 diabetes in women. Arch Intern Med 2004; 164:2235-2240

14.Montonen J, Knekt P, Harkanen $T$. Dietary patterns and the incidence of type 2 diabetes. Am J Epidemiol 2005; 161:219-227.

15.Salas-Salvad'o J, Bull'o $M$, Babio $N$. PREDIMED Study Investigators. Reduction in the incidence of type 2 diabetes with the Mediterranean diet: results of the PREDIMED-Reus nutrition intervention randomized trial. Diabetes Care 2011;34:14-19.

16. Ali H, Jarrar A, Sadig M, Yeatts K. Diet and carbohydrate food knowledge of multi-ethnic women: a comparative analysis of pregnant women with and without gestational diabetes mellitus. PLoS ONE 2013; 8(9): e73486.

17. Campbell $D$. The best age to become a mother. 2010 Des 31 [citied 2016 Nov 24]. Available from: https://www.theguardian.com/society/ 2010/dec/31/pregnancy-mothersfertility-children

18.Henig R. Henig $\mathbf{S}$. What's the best age to have a baby?. 2012 Nov 29 [citied 2016 November 24]. Available from: http://www.huffingtonpost.com/robin -marantz-henig/whats-the-best-ageto-hav_b_2206136.html

19. World Health Organization. World health statistcs. 2014 [citied 2016 Nov 24]. Available from: apps.who.int/iris/bitstream/10665/112 738/1/9789240692671_eng.pdf

20.Adiwiharyanto K. Hubungan antara tingkat pendidikan ibu hamil dengan keteraturan pemeriksaan kehamilan [skripsi]. Solo: Universitas Muhammadiyah Surakarta; 2008.

21.Notoatmodjo S. Promosi kesehatan dan ilmu perilaku. Jakarta: Rineka Cipta; 2007.

22. Kementrian Kesehatan RI Direktorat Jendral Bina Gizi dan Kesehatan Ibu dan Anak. Pedoman gizi seimbang 2014. [diakses 10 September 2016]. Tersedia dari http://gizi.depkes.go.id/pgs-2014-2

23.Santoso S, Ranti LA. Kesehatan dan gizi. Cetakan kedua. Jakarta: PT Rineka Cipta, 2004.

24. Widy US. Analisa pola makan ibu hamil dengan kondisi kurang energi kronik (kek) di kecamatan bobotsari, kabupaten purbalingga [skripsi]. Yogyakarta: Universitas Negeri Yogyakarta; 2014.

25.Hessie R. Analisis produksi dan konsumsi beras dalam negeri serta implikasinya terhadap swasembada beras di Indonesia [skripsi]. Bogor: Institut Pertanian Bogor; 2009.

26.Christianto E. Faktor yang memengaruhi volume impor beras di Indonesia. Jurnal JIBEKA. 2013;7:38-43.

27.Pemerintah Provinsi Sulawesi Utara. Seri analisis pembangunan wilayah provinsi sulawesi utara. 2015.

28. Kementrian Perikanan dan Kelautan RI. Tingkat konsumsi ikat tahun 20112015. 16 Apr 2016. [diakses 24 Nov 2016]. Tersedia dari: http://news.kkp.go.id/index.php/kons 
umsi-ikan-2011-2015/

29.Torjusen H, Lieblein G, Naes T, Haugen M, Meltzer HM, Brantsaeter AL. Food patterns and dietary quality associated with organic food consumption during pregnancy; data from a large cohort of pregnant women in Norway. BMC Public Health. 2012;12:612.

30.Daulay SS. Pengembangan minyak kelapa [karya tulis ilmiah hasil survei]. Kementrian Perindustrian Repuublik Indonesia; 2015.

31.Praditama AD. Pola makan ibu hamil dan pasca melahirkan di desa tiripan kecamatan berbek kabupaten nganjuk [skripsi]. Surabaya: Universitas Airlangga; 2013.

32.NNR Project Group: nordic nutrition recommendations. 4th edition. Copenhagen: Nordic Council of Ministers; 2004.

33. Institute of Medicine. Dietary reference intakes (dris): recommended dietary allowances and adequate intakes, total water and macronutrients. 2005.

34. Menteri Kesehatan Republik Indonesia. Peraturan menteri kesehatan republik indonesia nomor 75 tahun 2013 tentang angka kecukupan gizi yang dianjurkan bagi bangsa indonesia. 2013. 